Article

\title{
Using a Spatio-Temporal GIS Database to Monitor the Spatial Evolution of Urban Flooding Phenomena. The Case of Athens Metropolitan Area in Greece
}

\author{
Michalis Diakakis ${ }^{1}{ }^{*}$, Aggelos Pallikarakis ${ }^{2}$ and Katerina Katsetsiadou ${ }^{1}$ \\ 1 Faculty of Geology and Geoenvironment, National and Kapodistrian University of Athens, \\ Zografou GR15784, Greece; E-Mail: knavsika@geol.uoa.gr \\ 2 Department of Earth and Atmospheric Sciences, Agricultural University of Athens, 75 Iera Odos, \\ Athens GR11855, Greece; E-Mail: agpall@aua.gr \\ * Author to whom correspondence should be addressed; E-Mail: diakakism@ geol.uoa.gr; \\ Tel.: +30-210-727-4669; Fax: +30-210-263-7140.
}

Received: 26 December 2013; in revised form: 10 January 2014 / Accepted: 20 January 2014 / Published: 27 January 2014

\begin{abstract}
This work focuses on the spatial evolution of urban flooding phenomena in Athens metropolitan area, in Greece. The study examines the locations of flood-related damages and fatalities in Athens in 1880-2010, in comparison with the city's evolution, to identify possible changes in their spatial distribution. GIS software was used to develop a spatio-temporal database storing information on the location and timing of these flood-related incidents. The database was then used to determine and quantify spatio-temporal changes of flooding in the city. Results showed a gradual migration of areas subject to flooding from the central to the western part of Athens and finally to the northwestern and southern suburbs. This migration was accompanied by a significant increase of incidents in the newly built parts of the city and a simultaneous decrease at the oldest parts, following closely the city's spatial expansion over the study period. In addition, the study was able to identify and delineate particular parts of the city that experienced an increasing trend of flood incidents during the last decades and should be given priority in future flood risk mitigation actions.
\end{abstract}

Keywords: urban floods; flood risk; GIS; Athens; Greece; spatio-temporal databases 


\section{Introduction}

Floods pose a significant threat to human life [1] and cause extensive economic damages on a yearly basis [2,3]. Especially in urban environments, vulnerability is significantly increased as a higher concentration of population and assets makes flooding more costly and difficult to manage. In addition, given the complexity of socioeconomic activities in urban settlements, urban floods can potentially disrupt activities, businesses and social groups beyond the actual flooded area (e.g., disruption of transportation services). Moreover, the importance of urban floods in the overall risk is expected to grow even more [4] as global urban population is projected to increase further [5-7].

There is extensive literature and a well-established knowledge on how urban development affects basin hydrology, hydraulic conditions of channels and floodplains, as well as flood discharges and frequency [8-11]. In several cases, poorly planned development carried out to accommodate fast population increase has caused substantial changes in local hydrology and natural drainage networks [12]. In addition, it has led to the increase in vulnerability to flood risk through the urbanization of flood-prone areas [4]. Nevertheless, there is limited literature on how urban flooding phenomena evolve spatially in the long-term, influenced by changes in the urban environment.

Spatio-temporal databases have been used before to study temporal patterns of disasters and natural hazards [13-16]. In particular, GIS databases have proved to be an excellent tool to identify and quantify spatial changes and trends in natural hazards and other environmental phenomena [17].

The objective of this work was to provide a better understanding of the spatial evolution of flooding phenomena in Athens, Greece, given the city's significant expansion during the last century. To this aim, the study developed a spatio-temporal GIS database, containing information on the location and the timing of flood damages and fatalities in Athens, to identify possible changes and trends in the spatial migration of flooding phenomena and to illustrate their evolution throughout the study period. In addition, the study aims to identify and delineate particular areas of the city that present distinct increasing trends in the number of flood incidents, a result that has the potential to become a useful tool in strategic decision making regarding future flood risk mitigation actions.

\section{Study Area}

Athens is the capital and the most extensive urban area in Greece. The city is situated in central Greece, in the region of Attica and is built in a morphologic basin that occupies an area of approximately $534 \mathrm{~km}^{2}$, formed between Penteli, Parnitha, Ymittos and Aigaleo mountains and Saronikos Gulf in the south (Figure 1a). The basin is shaped primarily by Kifissos and Ilissos river networks. The area is relatively dry [18] with a mean annual rainfall of approximately $390 \mathrm{~mm}$ [19] and a poorly developed river network dominated by streams with small amounts of water for most of the year.

During the last century, Athens has been a rapidly evolving urban center, both in terms of population and spatial expansion, leading to a gradual urbanization of a significant part of the basin (Figure 1b) [20-23]. Nowadays, approximately 68\% of the basin is occupied by urban expanses that are host to about 4 million people [24]. 
Figure 1. (a) Map of Athens basin showing the river network, (b) the built areas and (c) the slope gradient of the basin.

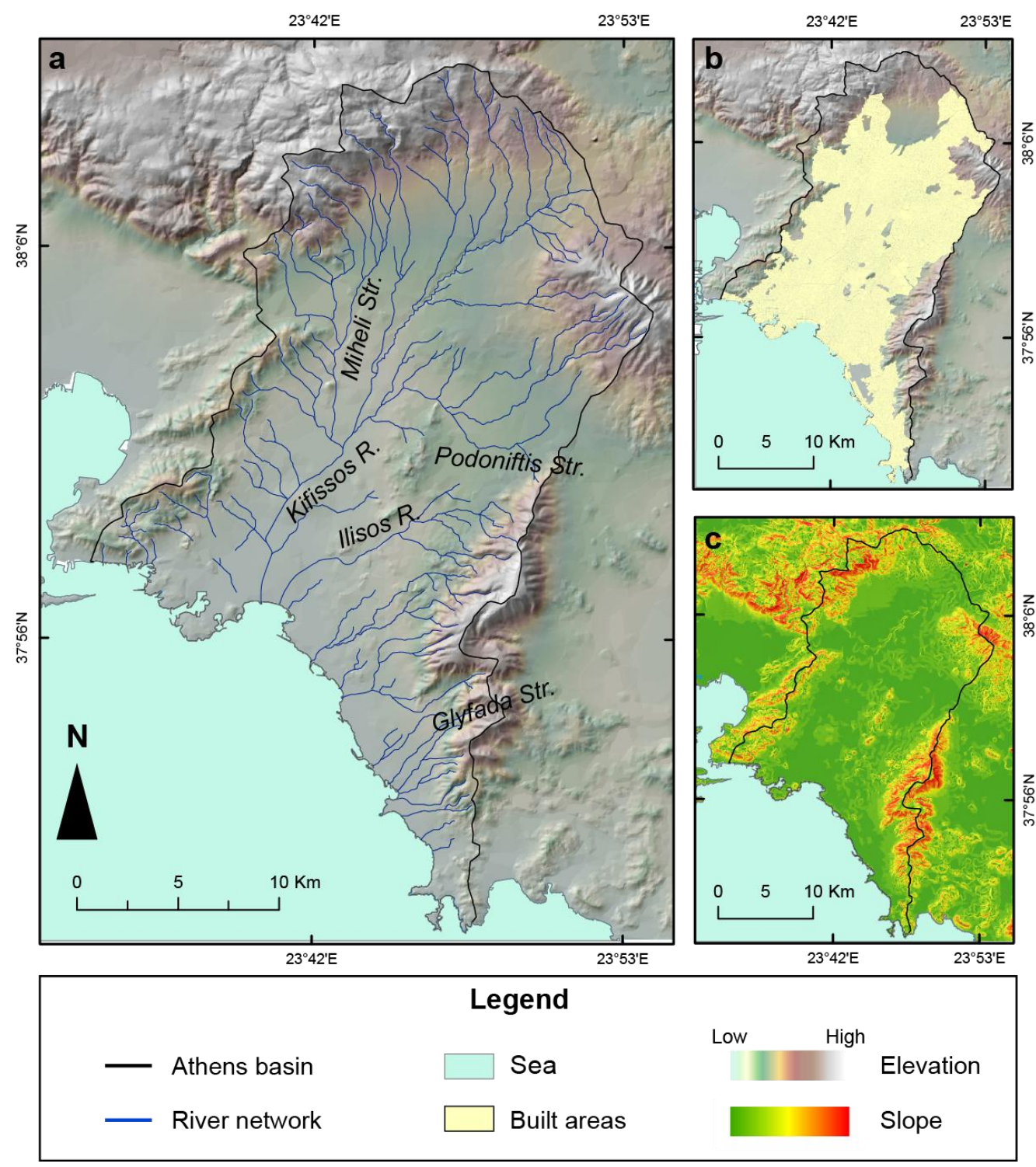

The increased pressure for development has led to the expansion of human activities and infrastructure within the vicinity of Athens' ephemeral watercourses, in many cases in areas of elevated flood hazard, not suitable for building. In fact, several authors suggest that poorly-planned development in the city has affected the drainage capacity of the river network noting that several parts of it were shrunk or converted into streets while critical river cross sections were diminished (Figure 2) [18,22,23,25].

Therefore, a combination of poor planning, extensive urbanization, reduction of soil infiltration capacity and building in flood-prone areas (Figure 2c) led to a rich record of floods events in the city [18,26-28]. In fact, detailed study of the temporal evolution of floods in the basin has shown a positive trend during the last century, and even though immediate loss of life is not showing clear increase [28], fatalities still remain an issue [29]. 
Figure 2. Typical examples of the condition of the drainage network in Athens including (a) cases of reduced cross sectional area due to bridge construction, (b) torrents covered or converted into streets and (c) buildings built directly alongside the riverbed in flood-prone areas.
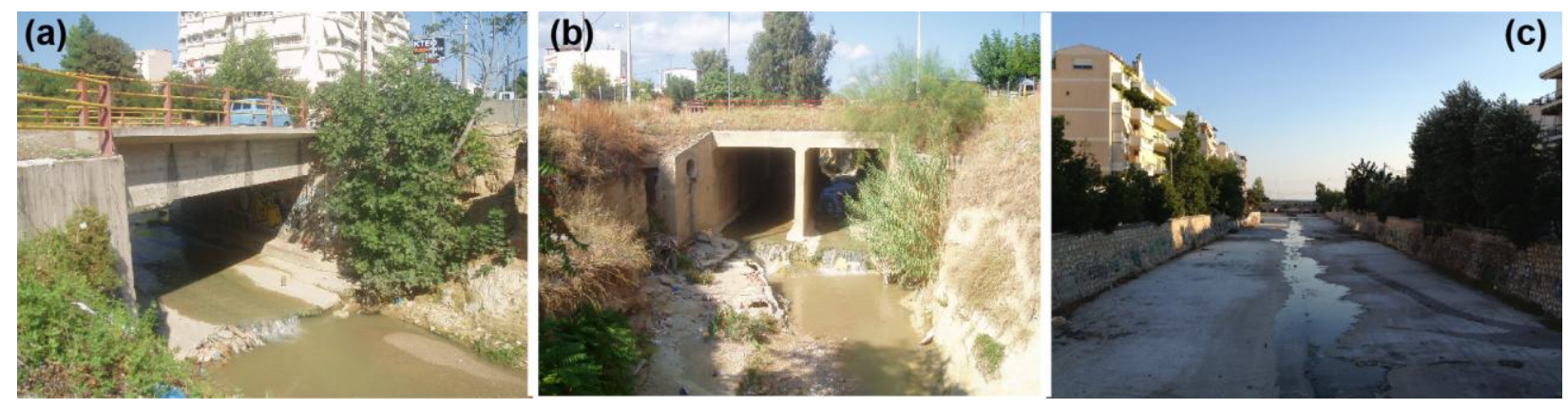

\section{Materials and Methods}

\subsection{Data}

Due to lack of instrumental data on river discharges, information on flood events for the study area had to be obtained from diverse sources including: (a) records enlisting damages and fatalities kept by public agencies; (b) published archives of the properties damaged; (c) press articles and (d) scientific reports. All these sources typically contained records of damaged properties and infrastructure and detailed descriptions of fatal incidents with details on the location and the time that they occurred.

In this work, the primary information on historical flood events over the study period (1880-2010) was the database developed by Diakakis [28] for Athens basin. This catalogue can be considered a complete inventory of flood events and fatalities in the study area as it encompasses all available sources of data, including official agencies archives, scientific sources and press databases [30]. The catalogue was used as the primary record upon which detailed information on the location and timing of damages and fatalities, induced by each flood event, were aggregated.

Data on the extent of the urban area were collected from maps corresponding to different periods [31-33] and were transferred in GIS.

\subsection{Methodology}

A GIS database was developed to store all available information. Each entry of the database corresponded to a damage or a fatality incident caused by flooding in the study area. Both categories are hereafter named with the general term "FIs" or "flood incidents". Information on each FI such as: (a) its exact location; (b) its date; and (c) its type (fatality or flood damage) were recorded and stored in the database. The locations of all FIs were plotted on the map of the study area and then arranged based on their dates in five groups. In a corresponding manner, the study period was divided in five segments, namely:

- segment P1 (1880-1920)

- segment P2 (1921-1940)

- segment P3 (1941-1960) 
- segment P4 (1961-1980)

- segment P5 (1981-2010)

The boundaries of these segments were specifically selected to represent important historical phases of the city's development, like the immigration waves of the 1920s, the post-war period of the 1940s and the 1950s, the rapid development during the 1960s and the 1970s, and the significant expansion of the city suburbs that occurred after 1980 [33]. The limits of the city's built areas during the corresponding time periods were also mapped for comparison purposes.

To examine possible changes in the spatial distribution of FIs the first method used was simple visual examination of their locations in the five different periods and comparison with the city's map at each time segment.

Then, to quantify possible migration of FIs in space the following method was used. After mapping the locations of all FIs, the study area was divided in $500 \mathrm{~m} \times 500 \mathrm{~m}$ cells forming a grid. Using ArcGIS 10.0 [34], the number of FIs in every cell of the grid was counted. Then, the value of the count was assigned to the respective cell. In total, five grids were produced corresponding to each of the five study periods (P1, P2, P3, P4 and P5) as described above. Then, each grid was compared to its previous one, through a cell-by-cell subtraction of cell values. This step was carried out to illustrate the differences in FI numbers between two successive periods and to quantify the extent of these differences. In this way, the method illustrated which parts of the study area experienced a change (increase or decrease) between successive periods and calculated the extent of this change. In total, four subtractions were conducted between the five grids, namely:

- P5 minus P4

- P4 minus P3

- P3 minus P2

- P2 minus P1

Each subtraction produced a resulting grid with cell values that corresponded to the result of this subtraction. Then, color symbology was used to illustrate the change in FI numbers and its magnitude.

Finally, simple visual comparison with the city's modern setting was carried out to define areas that present a noteworthy increasing or decreasing trend in flood incident numbers. The basic steps of the methodology are presented in Figure 3.

\subsection{Uncertainties}

In general, location information presented an overall good quality in all selected sources mainly due to the stationarity of city features that were used for spatial reference during the study period (i.e., street names, road network and landmarks). In general, the nature of data allowed identification of location through exact address or identified landmark, with a margin of error not more than $20 \mathrm{~m}$. However, in order to deal with the uncertainty associated with the non-scientific nature of part of the data, information on each FI was cross-checked in at least two independent sources.

With regard to the completeness of the event catalogue, it should be noted that the flood event and fatality records can be considered complete given the continuous presence of population in the area. 
Figure 3. Basic steps of the methodology. (a) Mapping incident locations for each period. (b) Development of grid. (c) Incident count on a cell-by-cell basis for each period. (d) Assignment of cell values based on the incident count. (e) Subtracting grids of different periods on a cell-by-cell basis. (f) Result of subtraction showing increase or decrease in cell values.

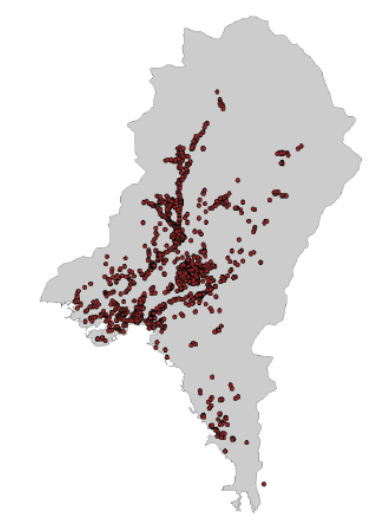

(a)

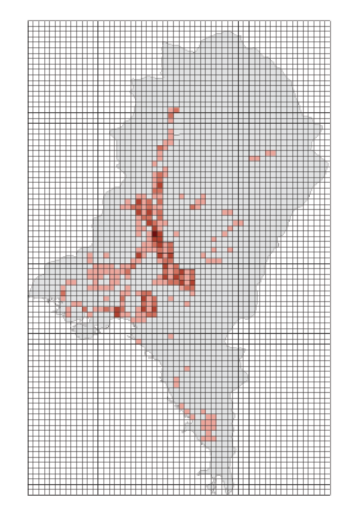

(d)
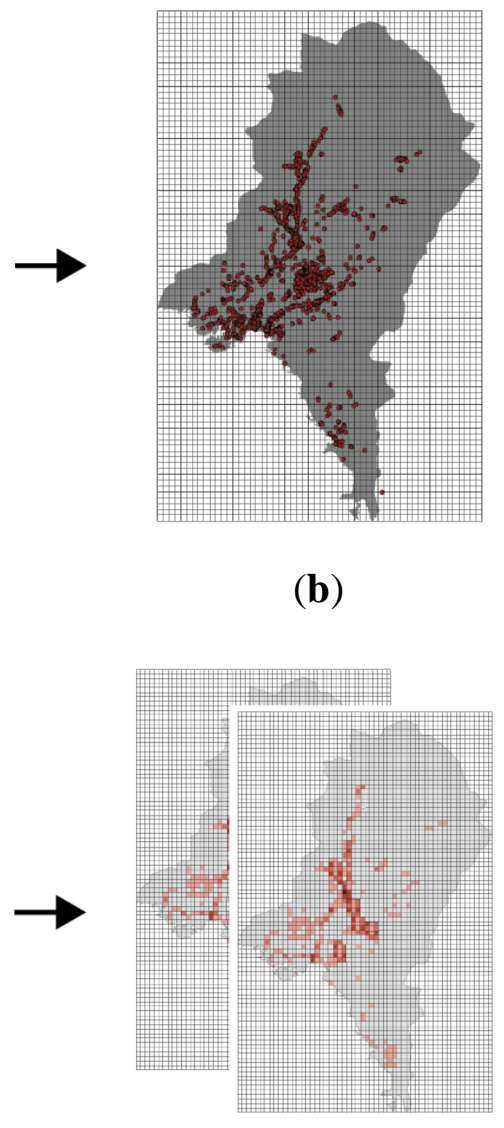

(e)

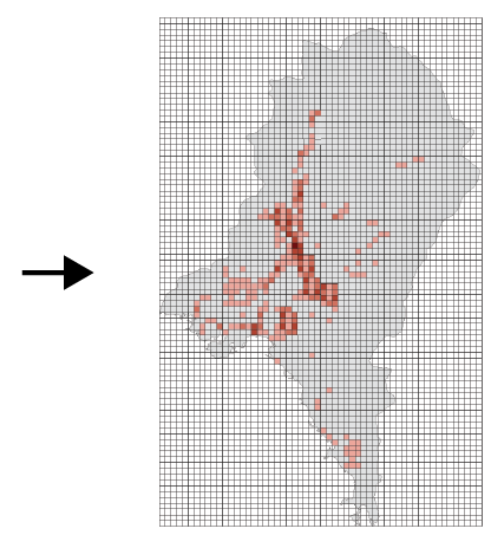

(c)

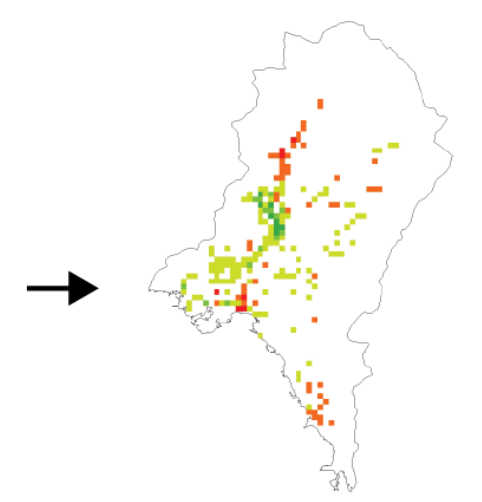

(f)

As far as the damages are concerned, it is important to note that uncertainty derives from the possibility of missing data or incomplete records, as authorities may have failed to report all damaged structures during a flood event. In this case, missing incidents are not expected to account for a substantial percentage of the total. Nevertheless, to minimize this uncertainty, all available sources recording flood damages in the area were studied, collecting all presently available information.

\section{Results and Discussion}

In total, 1,819 damages and 182 fatalities were recorded between 1880 and 2010 in Athens basin, caused by 52 flood events. A significant number of FIs was found to be clustered in the central part of the city in agreement with the findings of Nikolaidou and Chatzichristou [27] and Diakakis [28]. However, examination of their spatial distribution in different time segments showed a gradual dispersion of these incidents across Athens basin. Comparison with the evolution of the built areas showed that this dispersion follows the gradual expansion of the city throughout the study period (Figure 4). 
The dispersion of FI locations is evident mostly after 1960 (Figure 4b), after an extensive development of Athens towards the west and the northeast recorded between 1940 and 1980 (Figure 4a). Specifically, during the period from 1960 to 1980, a significant shift of FI locations towards the west is apparent, together with an increase in dispersion and a small but noticeable migration of FIs to the eastern and southern parts of the basin. During the same period, the city is expanded further towards all directions, however, the most dense and intensive development takes place at the western part [33]. Similarly, after 1980, the development of the northern and the southern suburbs of the city coincides with a further dispersion of FI locations towards the north and the south parts. In addition, a small migration of FI locations towards the east and northeast is also noticeable although it is considered limited in comparison with the extent of the city's growth in these areas.

Figure 4. (a) Spatial evolution of the city's built environment according to [31-33] and (b) of the flood-related incidents in five study periods. The dark and the light grey areas represent the limits of the city at the beginning and at the end of each period, respectively.
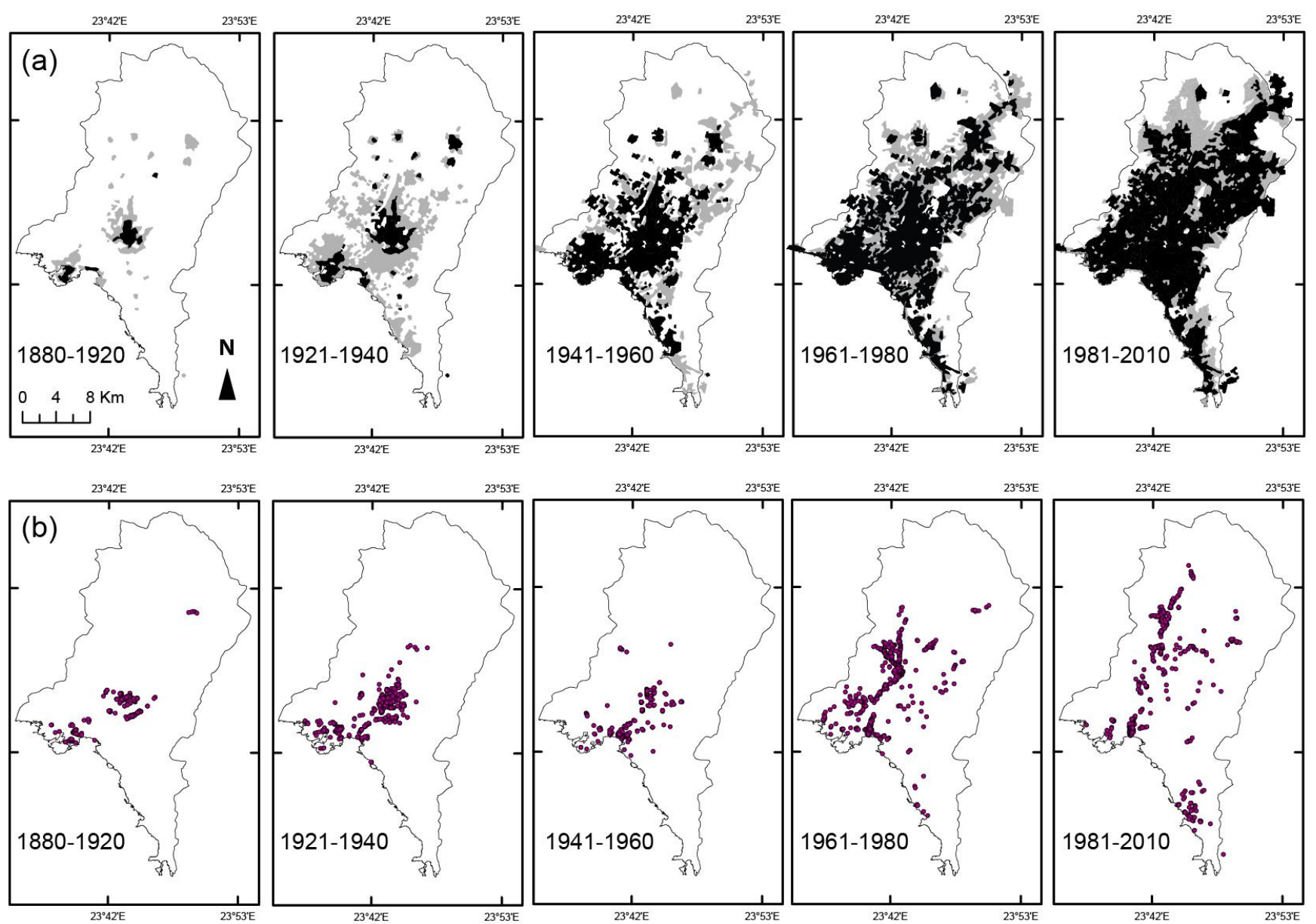

Despite the gradually increased dispersion in all five segments of the study period, the migration of FI locations towards the north and the west is much more extensive than towards the northeast, where the city has experienced significant development. This is attributed to the fact that the western and central part of the basin is developed within higher flood hazard areas, that is the floodplain of Kifissos river, which is the principal part of the local drainage network and the part with the richest flood record $[27,28]$. 
Quantification of spatio-temporal differences of incident locations between successive segments of the study period was possible through subtraction of grids on a cell-by-cell basis (Figure 5).

Figure 5. Spatio-temporal differences of incident locations count between successive segments of the study period through subtraction of respective grids on a cell-by-cell basis.

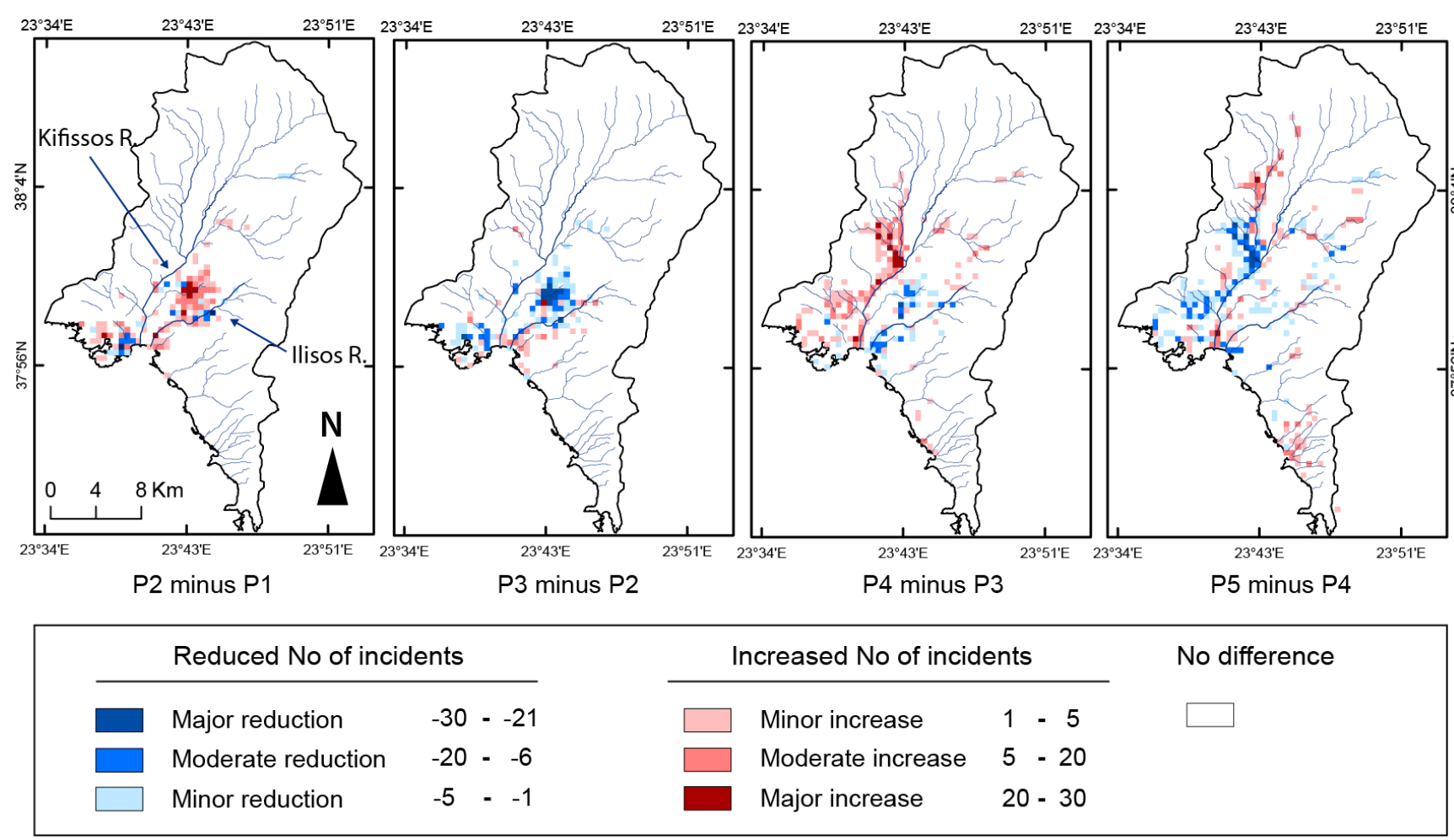

In detail, subtraction of P2 (1920-1940) from P1 (1880-1920) grid showed an important increase of FI numbers in central Athens, indicating an increase of incidents in this specific location. On the contrary, subtraction of P3 (1940-1960) from P2 (1920-1940) grid showed a decrease of FI numbers in the central part and a slight increase near the coast, southwest of the center where Kifissos and Ilissos flow into the sea. No significant shift in spatial terms is identified in this case. Nevertheless, a decline in their numbers is apparent. Subtraction of P4 (1960-1980) from P3 (1940-1960) grid shows an important shift in locations of FIs with a substantial and spatially extensive increase in the western part and a decrease in the central part of the city. Moreover, a minor but distinct increase is apparent in the east and northeast and in the south of the basin. At the coast, the number of FIs is showing a rise around Kifissos River mouth and a decrease around Ilissos mouth (shown in Figure 1), indicating a decline in flood events occurring in Ilissos basin. Finally, the subtraction of P5 (2010-1980) from P4 (1960-1980) grid shows an extensive decrease of incidents in the western part of the city and a moderate but clear increase in the northwest and the southern parts. In this case too, the area around the mouth of Kifissos is the only location in the oldest part of the city that presents an increase.

Overall, results show that after 1960, the number of FIs in the central part of the city is greatly reduced and a migration towards all directions is recorded. However, the prevalent shift is the one towards the west. After 1980, the increase in the southern suburbs becomes clear and a migration is recorded from the western part towards the northwest. Meanwhile, the western part of the city presents a substantial decrease in numbers, although FIs still exist after 1980 in this area (Figure 4b). This 
decrease in the older parts of the city shows a migration rather than an expansion of flooding phenomena towards the newest parts of Athens. This trend is attributed to structural measures taken after flood events in the central parts of the drainage network [28] that gradually improved the discharge capacity of the rivers, mitigating the local flooding problems. Such measures included building restrictions in the vicinity of rivers [35], bridge redesign using more durable construction materials (such as armed cement) and higher safety standards. In addition, in parts of the river network where floods occurred repeatedly, embankments were developed and channels were improved using gabions and concrete walls that provided higher discharge capacity, stable riverbanks and reduced erosion rates. Nevertheless, the area around the mouth of Kifissos River, although situated in the oldest part of the city (Figure 4a), records an increase in FI numbers in all consecutive periods, indicating a persistence of flood phenomena in the area (Figures $4 \mathrm{~b}$ and 5).

Given the importance of the 1960 change, a comparison was carried out, using the same method, between the locations of FIs before and after 1960. The result showed a substantial increase of flood-related incidents towards the west and the northwest, mostly along the route of Kifissos (Figure 6).

Figure 6. Change in flood-related incident numbers between the periods 1880-1960 and 1960-2010 in Athens metropolitan area.

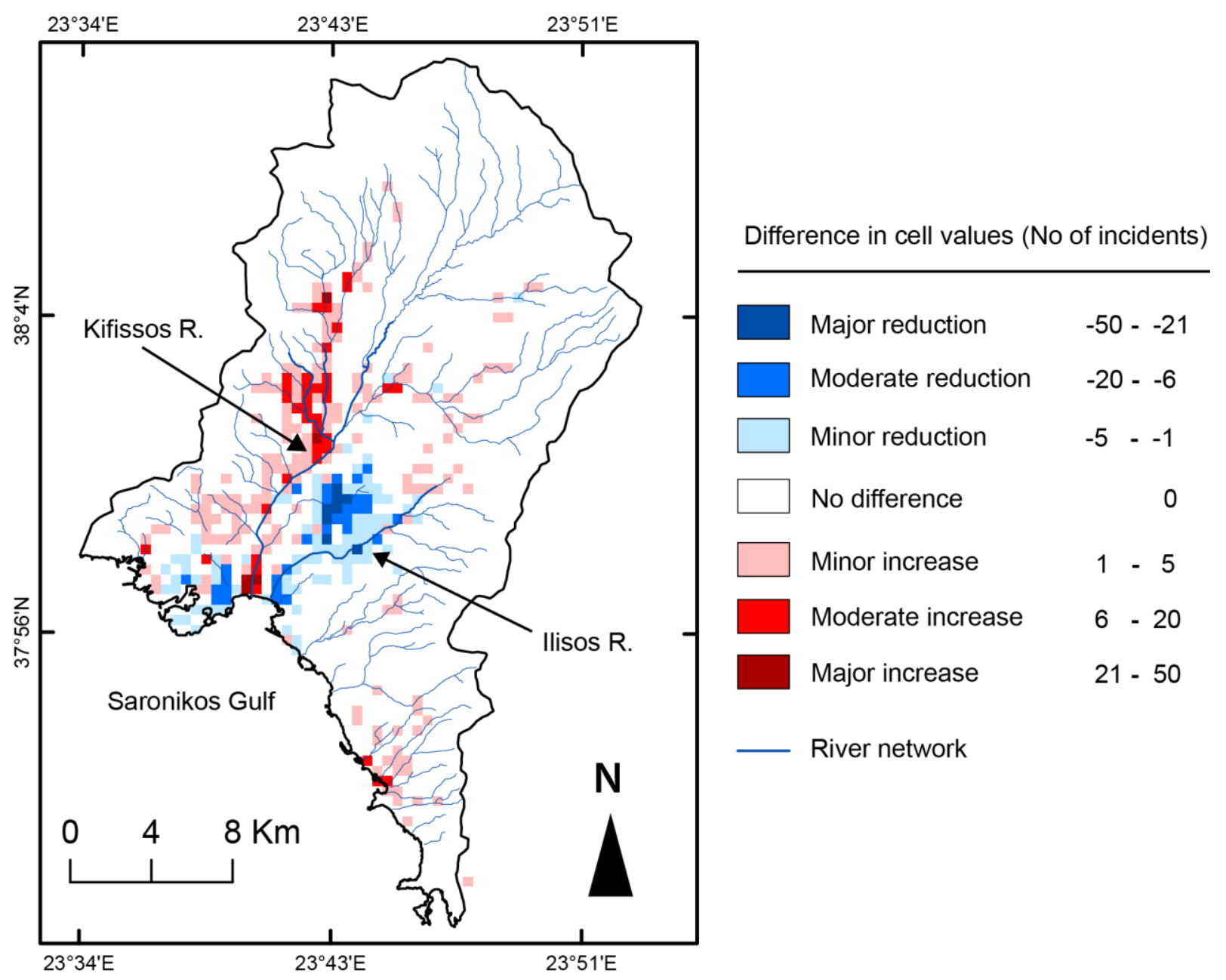

In addition, an increase was recorded in the southern suburbs. On the contrary, an important decrease in numbers of FIs is recorded in the central (and oldest) parts of the city. An exception to this decline is 
the area near the mouth of Kifissos River, which shows a spatially limited but substantial increase. Finally, the eastern and northeastern part of the basin presents a minor but clear rise in FI numbers.

Based on this comparison, the parts of the city that present distinct increasing or decreasing trends can be delineated (Figure 7).

Figure 7. Delineation of parts of the city presenting increasing and decreasing trends in flood-related incident numbers.
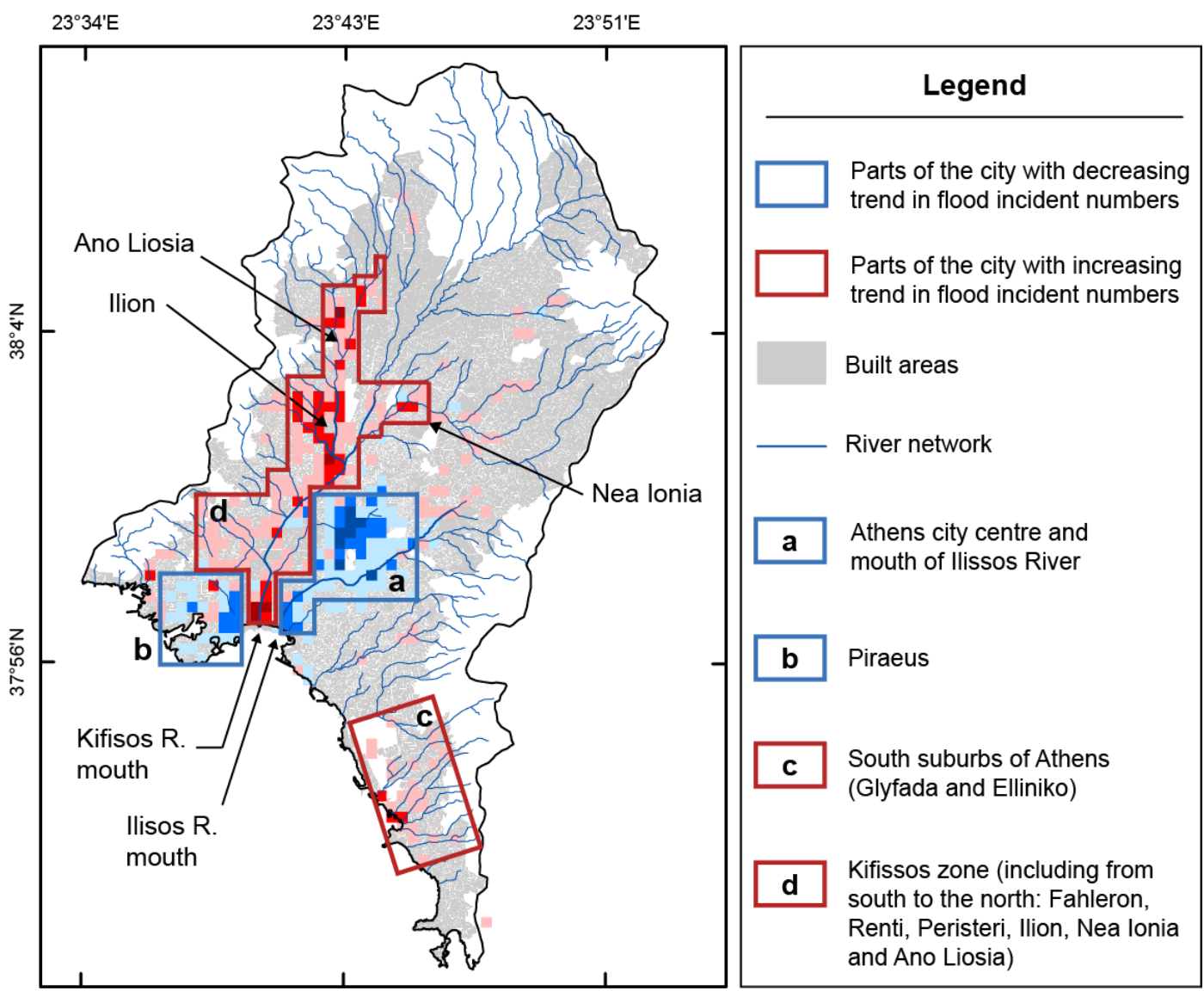

Difference in number of incidents

\begin{tabular}{|c|c|}
\hline Major reduction & $-50--21$ \\
\hline Moderate reduction & $-20=$ \\
\hline Minor reduction & $-5=$ \\
\hline
\end{tabular}

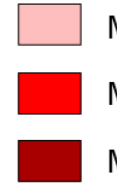

Minor increase

$1-5$

Moderate increase

$6-20$

Major increase

$21-50$

Two main areas of decrease in FI numbers can be identified at the central part of the basin at the oldest part of the city. One of them corresponds to the area of the city center of Athens, the main course of Ilissos River and its mouth on Saronikos Gulf (Figure 7a). The second one is the area around the port of Piraeus to the southwest of the basin. On the contrary, two parts of the city were found to present a general increasing trend. The first is located in the southern suburbs of the city (Figure 7c) near the municipalities of Glyfada and Elliniko. In this area, the increase is not widespread in spatial terms and not extensive in numbers, with the exception of some locations near the coastline.

The second area is extended mainly along the course of Kifissos River and its main tributaries (Figure 7d), over a number of different parts of the city such as Fahleron and Rentis at the southern 
end, Peristeri and Ilion (just northwest of the city center) and Ano Liossia on the northern end. Taking also into account the change that occurred after 1980 (shown in Figure 5), one can conclude that, since the 1980s, the highest rate of increase occurs in the northernmost part of this area (Figure 7d). However, substantial numbers of FIs still appear after 1980 in the western part of the basin.

The increasing trend identified in these areas is attributed to a combination of human interference with hydrological processes and natural susceptibility to flooding at these particular parts of the city. In detail, both areas experienced poorly planned and intensive development that gradually led to the decrease in the discharge capacity of the river network locally. In addition, expansion of the city in this particular part of the basin, that is the floodplain of Kifissos River and the southern suburbs, led to a substantial increase in exposure of buildings and infrastructure to high flood hazard, as dense development forced a large number of structures to be built adjacent to the river bed, in areas susceptible to flood.

Identification of the sections of the city where increasing trends are recorded is considered particularly important for flood risk mitigation. Civil protection and emergency management professionals can improve their decision making process for flood protection measures and actions by setting priorities based on the recorded trends. In addition, the performance of emergency management agencies can be improved by selecting optimum locations for emergency units and by focusing their flood risk studies on specific parts of the city where flood impact is increasing. Based on the conclusions of this study, local authorities in the locations where increase is identified (especially in the northwest and south part of the basin) should develop flood risk maps, maintain river beds and sewerage in good condition, examine the stability of the riverbanks and intervene with structural measures where needed, and study the adequacy of critical cross sections.

\section{Conclusions}

The study examined the spatial evolution of flood phenomena in Athens, Greece, using a spatio-temporal database. The methodology compared the distribution of flood incidents across the city in different time periods. Results showed a gradual dispersion of flood damages and fatalities from the central and oldest part of the city towards the outer parts, following the city's growth throughout the study period.

In general, the use of a spatio-temporal database exploited the spatial analysis capabilities of GIS in monitoring the locations of incidents in the rapidly changing and complex environment of a metropolitan area like Athens. The method succeeded to illustrate and quantify the gradual migration of flood-related incidents from the central part of the city towards the western and then the northwestern and the southern parts. Two significant shifts were identified in the course of the study period - in 1960 and in 1980, respectively_defining three major phases in the migration of flooding in Athens basin.

The results provided a better understanding of the impact of flooding in the study area. Although it was known in an anecdotal sense that flood impact had expanded to the outer parts of the city, the present analysis is unique in defining this migration in spatial terms, in showing its extent and in recording the important decline of migration numbers in the oldest parts of the city, introducing in this way a migration rather than an expansion concept. 
The analysis also identified particular areas of Athens that present increasing trends in flood incident numbers. This can be particularly useful for civil protection authorities as a guide during strategic decision making in setting priorities for flood mitigation measures.

\section{Author Contributions}

All authors contributed extensively to the development of the present study. Michalis Diakakis developed the concept and the research plan. Michalis Diakakis, Aggelos Pallikarakis and Katerina Katsetsiadou collected data, developed the GIS database and carried out spatial analysis. All authors shared equally the editing of the manuscript.

\section{Conflicts of Interest}

The authors declare no conflict of interest.

\section{References}

1. Jonkman, S.N.; Kelman, I. An analysis of the causes and circumstances of flood disaster deaths. Disasters 2005, 29, 75-97.

2. Barrero, J.I. Major flood disasters in Europe: 1950-2005. Nat. Hazard. 2007, 42, 125-148.

3. Barrero, J.I. Normalised flood losses in Europe: 1970-2006, Nat. Hazard. Earth Syst. Sci. 2009, 9, 97-104.

4. Jha, A.K.; Block, R.; Lamond, J. Cities and Flooding. In A Guide to Integrated Urban Flood Risk Management for the 21st Century; The World Bank: Washington, DC, USA, 2012; pp. 14-49.

5. Antrop, M. Landscape change and the urbanization process in Europe. Landsc. Urban Plan. 2004, 67, 9-26.

6. Champion, T. Urbanization, Suburbanisation, Counterurbanisation and Reurbanisation. In Handbook of Urban Studies; Paddison, R., Ed.; Sage: London, UK, 2001; pp. 143-161.

7. United Nations. World Urbanization Prospects; United Nations, Department of Economic and Social Affairs (DESA), Population Division, Population Estimates and Projections Section: New York, NY, USA, 2011.

8. James, J.D. Using a digital computer to estimate the effects of urban development on flood peaks. Water Resour. Res. 1965, 1, 223-234.

9. Hollis, G.E. The effect of urbanization on floods of different recurrence interval. Water Resour. Res. 1975, 11, 431-435.

10. Bailey, J.F.; Thomas, W.O; Wetzel, K.L.; Ross, T.J. Estimation of Flood-Frequency Characteristics and the Effects of Urbanization for Streams in the Philadelphia, Pennsylvania Area; US Geological Survey Water-Resources Investigations Report 87-4194; US Geological Survey: Philadelphia, PA, USA, 1989; p. 71.

11. Paul, M.J.; Meyer, J.L. Streams in the urban landscape. Annu. Rev. Ecol. Syst. 2001, 32, 333-365.

12. Barrera, A.; Llasat, M.C.; Barriendos, M. Estimation of extreme flash flood evolution in Barcelona County from 1351 to 2005. Nat. Hazards Earth Syst. Sci. 2006, 6, 505-518.

13. Abraham, T.; Roddick, J.F. Survey of spatio-temporal databases. GeoInformatica 1999, 3, 61-99. 
14. Venkateswara Rao, K.; Govardhan, A.; Chalapati Rao, K.V. Spatiotemporal data missing: Issues, tasks and application. Int. J. Comput. Sci. Eng. Surv. 2012, 3, 39-52.

15. Perez-Verdin, G.; Marquez-Linares, M.A.; Cortez-Ortiz, E.F. Spatiotemporal Distribution Patterns of Forest Fires in Northern Mexico. In Proceedings of the Fourth International Symposium on Fire Economics, Planning, and Policy: Climate Change and Wildfires, Mexico City, Mexico, 5-11 November 2012.

16. Stewart, K.; Glanville, J.L.; Bennett, D.A. Exploring spatiotemporal and social network factors in community response to a major flood disaster. Prof. Geogr. 2013, doi:10.1080/00330124.2013.799995.

17. Mennis, J.L.; Fountain, A.G. A spatio-temporal GIS database for monitoring Alpine Glacier change. Photogramm. Eng. Remote Sens. 2001, 67, 967-975.

18. Mimikou, M.; Baltas, E.; Varanou, E. A Study of Extreme Storm Events in the Greater Athens Area, Greece. In The Extremes of the Extremes, Extraordinary Floods; IAHS-AISH Publication: Reykjavik, Iceland, 2002; pp. 161-166.

19. Koutsoyiannis, D.; Baloutsos, G. Analysis of a long record of annual maximum rainfall in Athens, Greece, and design rainfall inferences, Nat. Hazards 2000, 22, 29-48.

20. Evelpidou, N.; Mamassis, N.; Vassilopoulos, A.; Markopoulos, C.; Koutsoyiannis, D. Flooding in Athens: The Kephisos River Flood Event of 21-22/10/1994. In Proceedings of the International Conference on Urban Flood Management, Paris, France, 25-27 November 2009.

21. Skilodimou, H.; Livaditis, G.; Bathrellos, G.; Verikiou-Papaspiridakou, E. Investigating the flooding events of the urban regions of Glyfada and Voula, Attica, Greece: A contribution to urban Geomorphology. Geogr. Ann. 2003, 85, 197-204.

22. Papazoi, V.; Nastos, P.; Philandras, C. Study of Flood Events in Attica (Urban and Rural Environment). In Proceedings of the 9th Pan-Hellenic Geographical Conference of the Hellenic Geographical Society, Athens, Greece, 4-6 November 2010.

23. Baltas, E.A.; Mimikou, M.A. Considerations for the Optimum Location of a C-band Weather Radar in the Athens Area. In Proceedings of the Second European Conference on Radar Meteorology (ERAD) in Conjunction with COST 717 Mid-Term Seminar, Delft, The Netherlands, 18-22 November 2002; pp. 348-351.

24. Hellenic Statistical Authority (ELSTAT). De Facto Population by Sex and Age Groups; Hellenic Statistical Authority: Athens, Greece, 2001.

25. Alexouli-Livaditi, A.; Vouvalidis, K.; Livaditis, G.; Pechlivanidou, S. Drainage network characteristics of Athens plain at the end of the 19th Century. Bull. Geol. Soc. Greece 2007, 40, 1513-1521.

26. Mimikou, M.; Koutsoyiannis, D. Extreme Floods in Greece: The Case of 1994. In Proceedings of the US-Italy Research Workshop on the Hydrometeorology, Impacts and Management of Extreme Floods, Perugia, Italy, 13-17 November 1995.

27. Nikolaidou, M.; Chatzichristou, E. Registering and Assessment of Devastating Floods in Greece and Cyprus. M.Sc. Thesis, National Technical University of Athens, Athens, Greece, 1995.

28. Diakakis, M. An inventory of flood events in Athens, Greece, during the last 130 years. Seasonality and spatial distribution. J. Flood Risk Manag. 2013, doi:10.1111/jfr3.12053. 
29. One Woman Dead and Thousands Stranded as Athens is Battered by Biggest Storm in 50 Years. Available online: http://www.dailymail.co.uk/news/article-2282815 (accessed on 2 August 2013).

30. Library of the Hellenic Parliament. Greek National Newspapers Archive; Library of the Hellenic Parliament: Athens, Greece, 2010.

31. EKKE (National Centre for Social Research). Social and Economic ATLAS of Greece; National Centre for Social Research: Athens, Greece, 2000.

32. Leontidou, L. Cities of Silence: Labor Colonization of Athens and Piraeus, 1909-1940; Cultural Technological Foundation ETBA: Athens, Greece, 2001.

33. Avdelidi, K. Spatial Evolution of 4 Major Greek Cities; National Centre for Social Research: Athens, Greece, 2010.

34. Environmental Systems Research Institute. ArcGIS Desktop: Release 10; Environmental Systems Research Institute: Redlands, CA, USA, 2011.

35. Hellenic Republic Official Gazette. On the Specification of Maximum Building Coefficient and Other Regulations of Planning Legislation; Hellenic Republic Official Gazette: Athens, Greece, 1979.

(C) 2014 by the authors; licensee MDPI, Basel, Switzerland. This article is an open access article distributed under the terms and conditions of the Creative Commons Attribution license (http://creativecommons.org/licenses/by/3.0/). 